\title{
IDENTIFIKASI KESULITAN CALON GURU TAMAN KANAK-KANAK DALAM MEMPELAJARI MUSIK
}

\section{Marwati Mansyur}

\begin{abstract}
The objectives of this research are to discover the difficulties faced by the students as the candidates for kindergarten teachers in studyint music, to identify the kinds of the difficulties, to know the students 'knowledge of musical instruments, and to measure the degrees of students' creativity in learning music. The research used survey conducted as from May through November 2005 in The Study Program of PGTK within the Department of Child Education, Schoolof Education, State University of Jakarta. The population covered all students of the Program Study of D-II PGTK which were doing music course. The respondents were choosen by random sampling technique with the total number of 40 students.

The result of the study show that (1) background knowledge of music in skill low, (2) reading musical notation is the most difficult to study, (3) the best known musical instrument is tambourine and the best known is castanyet and (4) student's creativity in learning music is categorized high.
\end{abstract}

Keywords : music, auditory perception, musical notice, creativity, early childhood education.

\section{PENDAHULUAN}

Program studi Guru Taman Kanak-kanak (PGTK) merupakan program studi yang meluluskan calon tenaga guru TK. PGTK juga diperlukan untuk mengantisipasi permasalahan terkait dengan kualitas lulusan calon guru TK yang memiliki kompetensi standar sebagaimana yang dibutuhkan masyarakat. Di lain pihak, lembaga TK menyelenggarakan pendidikan untuk mengembangkan kepribadian dan potensi diri sesuai dengan tahap perkembangan peserta didik. Permasalahan yang muncul adalah bekal apa saja yang diperlukan mahasiswa PGTK agar kelak mampu mengembangkan kepribadian dan potensi anak didik usia TK secara optimal?

Agar mahasiswa PGTK memiliki kompetensi standar sebagai guru TK, kepada mereka diberikan beberapa mata kuliah, di antaranya adalah mata kuliah musik. Pembelajaran musik merupakan pembelajaran untuk memberi kesempatan mengembangkan rasa keindahan kepada anak didik dengan mengalami dan menghayati bunyi ungkapan musik itu sendiri (Jamalus dan Busroh, 1991/1992: 1). Hal ini berarti rasa keindahan dapat memberi kesadaran kepada anak didik bahwa musik itu adalah bagian dari kehidupan. Musik dapat mengembangkan kepekaan anak didik terhadap lingkungannya dan dapat menghargai serta menikmati musik.

Pembelajaran musik pada program studi PGTK memerlukan kecermatan cara pelaksanaannya. Hal ini disebabkan karena mahasiswa PGTK nantinya akan menjadi guru di TK. Kegiatan dalam pembelajaran musik di PGTK dapat dikatakan sebagai pengalaman awal bermusik bagi mahasiswa. Oleh karena itu, pembelajaran musik diberikan secara menyenangkan dengan memberikan sentuhan pribadi yang memuaskan, dalam rangka membentuk pengalaman musik yang mampu mereka gunakan untuk mengungkapkan pemahaman secara bermakna, dinamis, dan variatif.

Tidak dapat dipungkiri bahwa bekal bermusik mahasiswa sangat minim sehingga mahasiswa mengalami kesulitan, misalnya tidak kreatif menyusun kalimat menjadi syair lagu yang sesuai tema; sama sekali tidak dapat memainkan alat musik; atau pengisian gerak dan tari yang tidak cocok dengan musiknya. Oleh karena itu, penelitian tentang identifikasi kesulitan mahasiswa calon guru TK belajar musik menjadi penting untuk direalisasikan. Hasil yang diperoleh akan memberikan umpan balik bagi dosen pengampu mata kuliah Musik I dan II dalam hal penentuan strategi pembelajarannya, materi-materi yang perlu mendapat penekanan, dan jenis alat musik mana yang benar-benar harus dikuasai mahasiswa.

Ruang lingkup masalah penelitian dibatasi pada identifikasi kesulitan mahasiswa calon guru TK dalam mempelajari musik. Permasalahan yang dapat dirumuskan adalah sebagai berikut. (1) Seberapa besar bekal mahasiswa calon guru TK untuk belajar musik? (2) Dimanakah letak kesulitan mahasiswa calon guru TK belajar musik? (3) Seberapa besar penguasaan mahasiswa calon guru TK terhadap alat musik? (4) Bagaimana kreativitas mahasiswa calon guru TK dalam belajar musik?

\section{KAJIAN TEORITIK}

TK merupakan bentuk pendidikan usia dini pada jalur pendidikan formal. Tujuannya adalah untuk 
membantu anak didik mengembangkan berbagai potensi baik psikis dan fisik yang meliputi moral dan nilai-nilai agama, sosial emosional, kognitif, bahasa, fisik/motorik, kemandirian, dan seni untuk siap memasuki pendidikan dasar (Anon, 2004:6). Aspek pengembangan moral dan nilai-nilai agama, serta pengembangan sosial, emosional, dan ke-mandirian termasuk bidang pengembangan pembiasaan, sedangkan aspek berbahasa, kognitif, fisik/motorik, dan seni termasuk bidang pengem-bangan kemampuan dasar. Tugas ini sangatlah berat. Oleh karena itu, timbul pertanyaan yaitu tenaga kependidikan yang bagaimanakah yang diperlukan dan mampu menjawab tantangan yang dihadapi dalam perkembangan pendidikan anak usia TK? Semestinya tenaga kependidikan calon guru TK disiapkan secara profesional.

Dalam rangka meletakkan dasar ke arah perkembangan moral, nilai-nilai agama, sosial emosional, kognitif, bahasa, fisik/motorik, kemandirian, dan seni, guru TK perlu memahami kemampuan yang harus dikuasai anak didik. Oleh karena itu, calon guru TK yang menempuh pendidikan setara D-II PGTK diberikan materi-materi esensial sebagai bekal pengembangan pembiasaan dan kemampuan dasar pada anak TK. Aspek perkembangan seni pada anak TK bertujuan agar anak mampu menciptakan sesuatu berdasarkan hasil imajinasinya, mengembangkan kepekaan, dan dapat menghargai hasil karya yang kreatif (Anon, 2004:7). Aspek perkembangan seni di backup oleh mata kuliah Musik I dan Musik II.

Musik merupakan media untuk mencurahkan pikiran dan rasa serta merupakan alat untuk berkomunikasi (Mahmud, 1995:8). Musik juga merupakan bunyi yang ungkapannya dapat ditanggapi melalui panca indera pendengaran untuk bernyanyi, bermain musik, dan bergerak mengikuti musik. Indra pendengaran yang ada pada telinga memberi informasi dalam bentuk persepsi auditif tentang berbagai suara, misalnya suara anak menyanyi, burung berkicau, dan lonceng berdentang. Menurut Moeslichatoen (1999:69), persepsi auditif akan membantu anak mengembangkan perbendaharaan pengetahuan dan memperluas wawasan, di antaranya anak dapat mengetahui: (1) setiap bunyi itu mempunyai sumber suara dan dapat dideskripsikan, (2) bunyi-bunyian itu dapat dibandingkan berdasarkan persamaan dan sumber suaranya, dan (3) bunyi-bunyian itu dapat digolongkan berdasarkan kesamaan sifat bunyi ke dalam satu penggolongan.
Hakikat musik memang bunyi, namun demikian tidak setiap bunyi tentu musik. Menurut Seashore (1997: 1-5), musik adalah medium (bunyi). Melalui bunyi dapat diungkapkan rasa gembira, sedih, patriotisme, sesal, dan pengharapan. Musik adalah pesona jiwa, alat yang mengangkat pikiran dan ingatan ke tingkat yang lebih tinggi, pintu gerbang menuju imajinasi. Hal ini yang menyebabkan seseorang bersinar matanya, nadinya berdenyut lebih cepat, menyebabkan emosi melampaui diri sendiri. Berdasarkan beberapa uraian tersebut, dapat disimpulkan bahwa musik adalah ilmu atau seni menyusun nada dalam urutan kombinasi untuk menghasilkan komposisi suara (bunyi) yang mempunyai kesatuan dan kesinambungan sehingga mengandung irama lagu dan keharmonisan.

Bernyanyi merupakan kegiatan yang penting di sekolah, terutama di TK dan SD. Apabila anak menyenangi kegiatan bernyanyi, maka akan mendapatkan pengalaman bernyanyi. Hal ini dapat memberikan kepuasan kepadanya, apalagi jika diiringi dengan bunyi yang berasal dari media tubuh sendiri, misalnya tepuk tangan, tepuk paha, dan hentakan kaki. Menurut Jamalus dan Busroh (1991/1992:7) bernyanyi merupakan alat bagi anak untuk mengungkapkan pikiran dan perasaannya. Pendidikan yang diberikan kepada anak didik di TK haruslah mencakup musik dan gerak tubuh. Gerak tubuh adalah alat yang baik bagi anak untuk menyatakan pikiran dan perasaannya sesuai dengan perkembangan dan pertumbuhannya. Apabila kepada anak diajarkan mengungkapkan musik melalui gerak maka pemahaman anak terhadap unsur-unsur musik akan berkembang lebih mantap.

Melalui lagu, anak akan merasakan berbagai perasaan sedih; senang; gembira; dan bahagia. Perasaan itu membawa untuk menghayati arti hormat pada orang tua, sayang sesamanya, kagum akan kebesaran Tuhan, cinta tanah air, dan sebagainya. Menurut Mahmud dan Fat (1994:1-2), nyanyian memiliki fungsi sosial selama nyanyian itu dikomunikasikan. Nyanyian juga dapat digunakan untuk mengembangkan kognitif anak.

Belajar mendengar dan mengapresiasikan nada musik bertujuan untuk mengembangkan kemampuan mendengar dan mengapresiasikan nada musik dengan cara menyenandungkan atau memainkan (dengan instrumen musik) nada irama bagi anak untuk ditebak. Menumbuhkan kemampuan bahasa dengan menyanyikan beberapa lagu anak-anak dan mengucapkan suku kata dalam nyanyian. Misalnya: la-lala, ma-ma-ma, ti-ti-ti, atau mi-mi-mi. 
Menumbuhkan dan mengembangkan kemampuan jasmani, misalnya bergerak bebas sesuai dengan irama musik, menggerakkan kepala, tangan, atau kaki sesuai dengan irama musik atau ritmik. Dengan demikian, menurut Hidayat (2003: 96-97), tujuan menyanyi dan bermain musik bagi anak-anak usia TK adalah untuk mencapai kemampuan dalam pengembangan daya cipta; bahasa; dan daya pikir. Menyanyi dan bermain musik juga dapat melatih motorik kasar dan halus, dengan melakukan senam irama, dan tanpa disadari anak bertambah perbendaharaan kata-kata baru melalui lagu-lagu/ nyanyian.

Mahasiswa program studi PGTK menempuh dua mata kuliah musik, yaitu Musik I dan Musik II masing-masing 2 SKS. Mata kuliah Musik I (2 SKS), memberikan pemahaman tentang notasi, birama dan irama, apresiasi musik, dan keterampilan menyanyi; penggunaan notasi, birama dan irama pada sebuah lagu; pengenalan dan pemahaman jenis musik dan lagu; serta penguasaan instrumen musik. Adapun mata kuliah Musik II memberikan keterampilan menyanyi dengan bantuan jenis alat musik, menciptakan lagu sederhana, pengisian notasi dan gerak dari sebuah lagu (Anon, 2002: 160). Alat musik yang diajarkan tidak hanya alat musik modern (piano dan organ) tetapi juga menggunakan media tubuh, misalnya tepuk tangan; suara mulut; dan alat musik media alam seperti bunyi batu dan kayu.

Materi-materi dalam mata kuliah Musik I dan Musik II juga harus dapat memberikan bekal mahasiswa calon guru TK untuk mengembangkan kemampuan dasar di bidang seni. Hasil belajar di bidang seni menurut kurikulum 2004 khususnya yang berhubungan dengan mata kuliah Musik I dan Musik II dirumuskan sebagai berikut. (1) Dapat menciptakan sesuatu dengan berbagai media (dengan indikator : membuat bunyi-bunyian dengan berbagai alat, menciptakan alat perkusi sederhana, bertepuk tangan dengan 2 pola). (2) Dapat mengekspresikan diri dalam bentuk gerak sederhana (indikatornya: menggerakkan kepala, tangan atau kaki sesuai dengan irama musik/ ritmik, mengekspresikan diri secara bebas sesuai irama musik, mengikuti gerakan tari sederhana sesuai irama musik, dan mengekspresikan diri dalam gerak bervariatif). (3) Dapat menyanyi dan memainkan alat musik sederhana (indikatornya: menyanyi 15-20 lagu anak-anak, bermain dengan berbagai alat musik perkusi sederhana). (4) Dapat menampilkan sajak sederhana (indikatornya: mengucapkan sajak dengan ekspresi, mengucapkan syair dari berbagai lagu sambil diiringi senandung lagunya, dapat melakukan gerakan pantomim sederhana, melakukan gerak pantomim secara sederhana, dan menceritakan gerak pantomim ke dalam bahasa lisan).

Seperti telah disinggung di depan, bahwa fungsi menyanyi pada anak dapat mengembangkan kreativitas. Hal ini akan tercapai apabila mereka diajar dan dibimbing oleh guru yang kreatif. Oleh karena itu, dalam belajar musik, kreativitas mahasiswa program D-II PGTK harus dikembangkan. Berikut dipaparkan tentang batasan kreativitas dalam belajar musik.

Kreativitas didefinisikan dalam berbagai cara tetapi orang lebih cenderung melihat dari sisi keterampilan, misalnya menggambar; memahat; menari; menyanyi; maupun berupa gagasan-gagasan (Chance, 1994: 148). Hal ini berarti kreativitas sangat spesifik kondisinya, penampilan atau semacam sesuatu hal yang mendekati tidak ada kebohongan atau sesuai dengan kenyataan. Kreativitas tampaknya menjadi bebas dan tidak mendapat pengaruh. Dalam seni, kreativitas anak tumbuh dengan jelas dan terjadi dengan sendirinya secara bebas serta dengan pendekatan alami yang ditunjukkan pada pembelajaran.

Menurut Mahmud dan Fat (1994:5), bernyanyi (bermusik) adalah kegiatan kreatif. Bernyanyi dengan ekspresi, bernyanyi dengan gaya, bernyanyi dengan gerak tari, bernyanyi me-ngembangkan imajinasi. Sebuah ciptaan nyanyian, betapa pun sederhananya, adalah hasil yang kreatif dan imajinatif. Dalam mengarang nyanyian, peranan kreativitas dan imajinasi dapat menentukan kualitas suatu ciptaan nyanyian. Oleh karena itu, aktivitas seseorang yang kreatif ketika belajar musik akan terlihat pada rasa ingin tahu dan ingin mencoba sebuah lagu, atau suatu alat musik. Hal ini sesuai dengan pendapat Mahmud dan Fat (1994:87) menyatakan bahwa bermusik adalah aktivitas kreatif seorang anak, antara lain tampak pada rasa ingin tahu; ingin mencoba; dan daya imajinasinya menjadi berkembang. Kreativitas bertujuan untuk memantap-kan dan mengembangkan pengetahuan dan keteram-pilan musik yang telah diperoleh, misalnya dengan jalan mencoba dan memilih alat musik perkusi yang sesuai untuk mengungkapkan isi dan maksud musik atau nyanyian yang diiringi.

\section{METODOLOGI PENELITIAN}

Penelitian bertujuan untuk mengidentifikasi kesulitan mahasiswa calon guru TK dalam mempelajari musik. Penelitian dengan metode survei, dilaksanakan di program studi PGTK, Jurusan Pendidikan Anak, FIP UNJ. Waktu penelitian adalah 
bulan Mei 2005 sampai dengan bulan November 2005 pada mahasiswa yang mengambil mata kuliah Musik tahun akademik 2005/2006.

Populasi target penelitian ini adalah mahasiswa program D-II PGTK FIP UNJ. Populasi terjangkaunya adalah mahasiswa program D-II PGTK FIP UNJ yang sedang menempuh mata kuliah Musik I. Pengambilan sampel dilakukan dengan simple random sampling. Dari 70 mahasiswa yang mengambil mata kuliah Musik I, diambil secara random 40 mahasiswa untuk dijadikan sampel penelitian.

Pada penelitian ini menggunakan instrumen berupa tes tindakan/penampilan/ keterampilan dan instrumen kreativitas belajar musik. Tes kreativitas

\section{HASIL PENELITIAN}

Permasalah penelitian ini meliputi empat kelompok. Hasil penelitian terhadap keempat kelompok tersebut adalah sebagai berikut. berupa lagu, siswa membuat partitur musik dengan alat perkusi dan alat tiup yang sederhana, kemudian diuji cobakan.

Pengumpulan data dilaksanakan pada awal, selama proses, dan akhir proses perkuliahan Musik I. Pengumpulan data menggunakan lembaran observasi dan tes kreativitas belajar musik. Kegiatan analisis data terdiri dari analisis deskriptif dan analisis statistik. Kegiatan analisis deskriptif berdasarkan lembaran observasi. Analisis statistik berdasarkan tes kreativitas belajar musik untuk mengetahui tingkat kreativitas mahasiswa dalam belajar musik. Data diolah dalam bentuk sesuai dengan kebutuhan, dengan skor tertinggi 4 dan skor terendah 1.

\section{Bekal Mahasiswa Untuk Belajar Musik}

Untuk memperoleh gambaran tentang bekal belajar musik yang telah dimiliki mahasiswa dilakukan observasi pada awal perkuliahan, digunakan lembar observasi. Data yang diperoleh seperti tampak pada tabel berikut.

Tabel 1. Bekal Mahasiswa Belajar Musik

\begin{tabular}{|l|l|l|}
\hline No. & Keterangan & Rerata Skor \\
\hline 1. & Membaca not angka & 2,125 \\
\hline 2. & Membaca not balok & 2,025 \\
\hline 3. & $\begin{array}{l}\text { Membaca nilai not dengan birama 3/4,2/4,4/4 dengan } \\
\text { tepukan/pukul meja }\end{array}$ & 2,225 \\
\hline 4. & Membaca syair lagu dengan tepat & 2,175 \\
\hline 5. & Bergerak sesuai dengan isi lagu & 2,300 \\
\hline
\end{tabular}

Terlihat pada Tabel 1 di atas tentang bekal mahasiswa belajar musik, ternyata membaca not balok adalah yang paling rendah. Hal ini disebabkan karena mahasiswa tidak mempunyai dasar musik yang standar. Jika hasil ini dibandingkan dengan bekal mahasiswa membaca not angka, hal ini pun masih rendah, yaitu dengan rerata 2,125. Berdasarkan hasil observasi mengenai membaca not angka dan not balok, dapat dikatakan bahwa mereka kurang mempunyai dasar-dasar bermain musik. Hal ini menunjukkan bahwa input mahasiswa PGTK tentang bermusik kurang sekali. Bekal mahasiswa untuk bergerak sesuai dengan isi lagu dengan rerata 2,300 merupakan bekal yang tertinggi. Hal ini diperkirakan karena dalam kehidupan sehari-hari tanpa mereka sadari timbul gerakan, misalnya ketika mendengar musik, juga dalam kehidupan sehari-hari mereka berolah raga, misalnya senam yang diiringi dengan musik sehingga secara otomatis badan bergerak.

\section{Kesulitan Mahasiswa Belajar Musik}

Untuk memperoleh gambaran tentang kesulitan belajar musik dilakukan observasi pada proses perkuliahan dengan menggunakan lembar observasi. Data yang diperoleh seperti tampak pada Tabel 2 berikut.

Tabel 2. Kesulitan Mahasiswa Belajar Musik

\begin{tabular}{|l|l|l|}
\hline No. & Keterangan & Rerata Skor \\
\hline 1. & Membaca not angka & 2,825 \\
\hline 2. & Membaca not balok & 3,000 \\
\hline 3. & $\begin{array}{l}\text { Membaca nilai not dengan birama 3/4, 2/4, 4/4 dengan } \\
\text { tepukan/pukul meja }\end{array}$ & 3,075 \\
\hline 4. & Membaca syair lagu dengan tepat & 3,425 \\
\hline 5. & Bergerak sesuai dengan isi lagu & 3,550 \\
\hline
\end{tabular}


Mahasiswa calon guru TK pada dasarnya tidak mempunyai dasar-dasar untuk bermain musik. Hal ini disebabkan karena bayangan mereka yang salah tentang bermusik. Mereka mengira bahwa bermain musik itu sulit dan memerlukan bakat sehingga tanpa bakat tidak akan mampu bermain musik, ini adalah pendapat yang salah. Terlihat pada Tabel 2 di atas, bahwa keempat komponen mempunyai rerata di atas 3,00 artinya dalam membaca not balok; membaca nilai not dengan birama 2/4,3/4, dan 4/4 dengan tepukan/ pukul meja; membaca syair lagu dengan tepat dan bergerak sesuai dengan isi lagu; dan dapat dikatakan mereka tidak mengalami kesulitan serta mereka menyenangi kegiatan-kegiatan praktik musik tersebut. Namun demikian, mereka masih mengalami kesulitan dalam membaca not angka, ditunjukkan dengan perolehan rerata 2,825. Hal ini dapat terjadi karena (1) jarang berlatih solmisasi, (2) tidak mau membuka mulut secara maksimal sesuai tuntutan bervokal, (3) mahasiswa tidak mau mempelajari nilai-nilai not, sehingga sulit bagi mereka untuk membaca not, mereka hanya mengikuti iringan musik saja, tetapi ketika musiknya tidak ada mereka tidak bisa membaca notasi.

\section{Penguasaan Mahasiswa tentang Alat Musik}

Untuk pengambilan data tentang penguasaan alat musik dilakukan observasi pada proses pembelajaran. Mereka diberi kesempatan untuk berlatih sendiri-sendiri memainkan semua alat musik yang disediakan, kemudian berkelompok untuk memainkan semua alat musik. Di sini akan terlihat atau terdengar apakah permainan alat musik tersebut sudah menyatu atau belum sesuai dengan partitur lagu. Data yang diperoleh tampak pada tabel berikut ini.

Tabel 3. Penguasaan Mahasiswa tentang Alat Musik

\begin{tabular}{|l|l|l|}
\hline No. & Alat Musik & Rerata Skor \\
\hline 1. & Tamborin & 3,650 \\
\hline 2. & Castanyet & 3,200 \\
\hline 3. & Ringbell & 3,225 \\
\hline 4. & Triangel & 3,475 \\
\hline 5. & Recorder Sopran & 3,450 \\
\hline
\end{tabular}

Jika dilihat penguasaan mahasiswa dalam memainkan alat musik, pertama kali mahasiswa takut untuk memainkan alat musik tersebut. Karena tuntutan kompetensi menjadi guru TK, mereka harus berusaha belajar memainkan alat musik sederhana. Ternyata setelah belajar, mereka tertarik dan menyenanginya. Akibatnya kemampuan mereka memainkan alat musik tinggi. Hal ini terlihat rerata skor yang diperoleh ketika memainkan alat musik lebih dari 3,00. Penguasaan alat musik tertinggi adalah tamborin, hal ini disebabkan karena alat ini mudah memainkannya dan enak didengar. Penguasaan alat musik yang paling rendah adalah ketika memainkan alat musik castanyet, mereka harus selalu berkonsentrasi agar tidak ketinggalan. Begitu mereka kehilangan konsentrasi mereka menjadi ketinggalan dan akibatnya salah hitungan.

\section{Kreativitas Mahasiswa dalam Belajar Musik}

Kreativitas mahasiswa dalam belajar musik yang dimaksud di sini adalah bagaimana mahasiswa bermain musik sendiri-sendiri tanpa bimbingan. Sesudah itu mereka bermain musik secara berkelompok tanpa bimbingan. Ternyata mereka menemukan bahwa bermain musik itu indah. Akibatnya mereka belajar membuat partitur sendiri untuk mengiringi lagu baru. Guna melihat seberapa tinggi tingkat kreativitas mahasiswa belajar musik diberikan tes pada akhir proses pembelajaran. Hasil yang diperoleh pada tes kreativitas belajar musik ditunjukkan dengan rerata 3,575. Hasil ini menunjukkan bahwa tingkat kreativitas mahasiswa dalam belajar musik termasuk kategori tinggi.

\section{KESIMPULAN}

Berdasarkan hasil penelitian, maka dapat diambil kesimpulan sebagai berikut.

1. Bekal belajar musik yang dimiliki mahasiswa masih rendah, ditunjukkan dengan rerata skor tidak lebih dari 2,500. Bekal bermusik paling rendah adalah membaca not balok, sedangkan bekal tertinggi adalah bergerak sesuai dengan isi lagu.

2. Teridentifikasi bahwa membaca not angka merupakan yang paling sulit, sedangkan mahasiswa hampir tidak mengalami kesulitan ketika bergerak sesuai dengan isi lagu. 
3. PGTK adalah tamborin, sedangkan yang kurang dikuasai adalah castanyet.

4. Tingkat kreativitas mahasiswa PGTK belajar musik dalam kategori tinggi, ditunjukkan dengan rerata skor 3,575.

Upaya untuk mengetahui tinggi rendahnya bekal mahasiswa belajar musik dapat dilakukan oleh program studi PGTK ketika diadakan tes masuk calon mahasiswa PGTK, yakni dengan mengadakan tes khusus penguasaan bermusik. Calon mahasiswa disuruh membaca notasi balok, notasi solmisasi, dan memainkan beberapa alat musik. Dengan cara ini, akan diketahui calon-calon mahasiswa mana yang sudah menguasai musik. Tes khusus penguasaan bermusik ini juga dapat mengantisipasi kesulitan membaca notasi angka yang diidentifikasi paling sulit.

Dosen pengampu mata kuliah Musik harus menitikberatkan pada pembacaan notasi angka (solmisasi), kemudian notasi balok. Dosen pengampu mata kuliah Musik dapat menugaskan mahasiswa untuk menambah frekuensi dalam mendengarkan musik karena dengan bertambah lama mendengarkan dan merasakan musik akan semakin banyak pula ia mengenyam rasa dan semakin terbiasa ia mencari pengalaman dalam dunia musik terutama musik tiup dan musik perkusi, serta tidak lupa menyanyi (membaca notasi).

Upaya untuk meningkatkan penguasaan alat musik bagi mahasiswa PGTK selain alat musik tamborin yang mudah dimainkan adalah dengan menekankan pada alat musik castanyet. Program studi PGTK dapat memperbanyak alat musik castanyet ini agar setiap mahasiswa dapat leluasa berlatih memainkan alat musik ini.

Apabila dilihat dari tingkat kreativitas, maka ditemukan bahwa kreativitas mahasiswa PGTK belajar musik dalam kategori tinggi, ditunjukkan dengan rerata skor 3,575. Hasil ini menggembirakan, namun tetap perlu diupayakan agar mahasiswa calon guru TK lebih kreatif lagi. Upaya yang perlu dilakukan adalah membiasakan mereka untuk bermusik sesering mungkin, tidak hanya ketika mereka menempuh mata kuliah musik saja.

Berdasarkan uraian di atas, dapat diberikan saran sebagai berikut. (1) Bagi calon guru TK, setelah mengetahui dan merasakan bahwa musik itu indah, maka kemampuan yang telah dimiliki harus dipertahankan dan dapat dikembangkan untuk lagulagu yang lain dan bervariatif untuk dikembangkan di sekolah tempat mahasiswa mengajar nanti. (2) Bagi dosen pengampu mata kuliah Musik I dan Musik II, hasil penelitian ini sebagai masukan untuk perbaikan pembelajaran di masa yang akan datang. (3) Bagi program studi PGTK, hasil ini dapat dijadikan sebagai pedoman dalam menjaring input mahasiswa PGTK. Hasil penelitian ini juga mendorong program studi PGTK untuk melengkapi dan memperbanyak alat-alat musik perkusi. (4) Bagi pembaca, dapat melakukan penelitian lanjutan yang lebih kompleks.

\section{DAFTAR PUSTAKA}

Anon. (2002). Pedoman kegiatan akademik Universitas Negeri Jakarta. Jakarta: UNJ.

Anon. (2004). Kurikulum TK dan RA: Standarkompetensi. Jakarta: Departemen Pendidikan Nasional, Direktorat Jenderal Pendidikan Dasar dan Menengah, Direktorat Pendidikan TK dan SD.

Chance, P. (1994). Learning and behavior. Pacific Grove, California: Brooks/Cole Publishing Company.

Hidayat, H. (2003). Aktivitas mengajar anak TK: Panduan mahasiswa PGTK/PGRA, guru, dan orang Tua. Bandung: Katarsis.

Jamalus, dan Busroh, H. (1991/1992) Pendidikan kesenian I (musik). Jakarta: Departemen Pendidikan dan Kebudayaan, Direktorat Jenderal Pendidikan Tinggi, Proyek Pembinaan Tenaga Kependidikan.

Mahmud, A.T.(1995). Musik dan anak. Jakarta: Departemen Pendidikan dan Kebudayaan, Direktorat Jenderal Pendidikan Tinggi.

Mahmud, A.T. dan Fat. (1994). Petunjuk teknis proses belajar mengajar di Taman Kanak-kanak. Jakarta: Departemen Pendidikan dan Kebudayaan, Direktorat Jenderal Pendidikan Dasar dan Menengah, Bagian Proyek Peningkatan Mutu Taman Kanak-kanak.

Moeslichatoen. (1999). Metode Pengajaran di Taman Kanak-kanak. Jakarta: Rineka Cipta.

Seashore, C. E. Psychology of Music. (1967). New York: Dover Publications, Inc.,.

\section{KETERANGAN PENULIS}

Dra. Marwati, M.Pd., dilahirkan di Padang, Maret 1953. Penulis aktif mengajar di Universitas Terbuka UNJ hingga tahun 2007. saat ini penulis aktif mengajar di PGSD UNJ. 